\title{
Consolidatie-uitsluiting wegens afwijkende bedrijfsactiviteiten
}

\section{Drs. Ruud G. A. Vergoossen}

\section{Inleiding ${ }^{1}$}

De activiteiten van met name concerns vinden doorgaans plaats in afzonderlijke juridische eenheden. Ter verkrijging van een adequaat inzicht in de financiële positie en de behaalde resultaten van een concern is vooral de geconsolideerde jaarrekening van belang. De vennootschappelijke jaarrekening van de moedermaatschappij speelt hierbij een ondergeschikte rol, hoewel formeel bezien de geconsolideerde jaarrekening slechts een onderdeel is van de toelichting op deze vennootschappelijke jaarrekening.

Van belang in dit kader is de bepaling van de consolidatiekring. Met andere woorden, welke maatschappijen moeten met de jaarrekening van de moedermaatschappij worden meegeconsolideerd?

In de Verenigde Staten geldt dat in principe alle deelnemingen waarin de moedermaatschappij meer dan de helft van de stemrechten heeft (majority-owned subsidiaries) in de consolidatie dienen te worden betrokken. In ons land staat bij de bepaling van de consolidatiekring het groepsbegrip centraal. Een groep wordt daarbij omschreven als een economische eenheid waarin rechtspersonen en vennootschappen organisatorisch zijn verbonden. De consolidatiekring wordt in principe gevormd door de maatschappij die aan het hoofd van de groep staat en de groepsmaatschappijen. ${ }^{2}$

Voor wat betreft de uitzonderingen die op de gehanteerde consolidatieregels gelden, bestaat tussen de Nederlandse wetgeving en Amerikaanse regelgeving een significant verschil. Volgens de Nederlandse wetgeving namelijk dienen groepsmaatschappijen met afwijkende bedrijfsactiviteiten niet te worden meegeconsolideerd, indien consolidatie in strijd zou zijn met het wettelijk vereiste inzicht. ${ }^{3}$ Dit is conform de Zevende EG-richtlijn. In de Verenigde Staten daarentegen is in 1988 de consolidatie-uitsluiting wegens branchevreemde activiteiten komen te vervallen. Ook het International Accounting Standards Committee (IASC) heeft de uitsluitingsclausule wegens afwijkende bedrijfsactiviteiten onlangs geschrapt.

In dit artikel worden de achtergronden van beide visies omtrent deze uitsluitingsclausule nader beschouwd en met elkaar vergeleken. Verder wordt nagegaan in hoeverre in Nederland een beroep wordt gedaan op de uitzonderingsclausule wegens afwijkende bedrijfsactiviteiten en in hoeverre dit terecht is geschied. Echter alvorens dit te doen zal ik in het kort ingaan op de effecten van consolidatie.

\section{Effecten van consolidatie}

De geconsolideerde jaarrekening wordt beïnvloed door de omvang en samenstelling van de consolidatiekring. Door het meeconsolideren van een deelneming wordt de balanspost 'Deelnemingen', voor zover betrekking hebbend op deze deelneming, uitgesplitst in de afzonderlijke bezittingen en schulden van de deelneming. Verder wordt in de winst- en verliesrekening het in de

Drs. Ruud G. A. Vergoossen studeerde bedrijfseconomie aan de Erasmus Universiteit te Rotterdam. Thans is hij als universitair docent verbonden aan de Faculteit der Economische Wetenschappen en Econometrie van de Vrije Universiteit te Amsterdam. 


\section{MAB}

post 'Resultaat uit deelnemingen' opgenomen resultaat van deze deelneming uitgesplitst in de afzonderlijke opbrengsten- en kostenposten. Wanneer een deelneming wordt gewaardeerd tegen nettovermogenswaard $e^{4}$ heeft consolidatie geen invloed op het in de geconsolideerde balans opgenomen eigen vermogen. Ook het eindcijfer van de geconsolideerde resultatenrekening blijft dan ongewijzigd.

Het totaal vermogen in de geconsolideerde balans wordt daarentegen wel beïnvloed. De balanstellingen nemen namelijk toe met het bedrag van de schulden van de geconsolideerde deelneming en met het minderheidsaandeel van derden indien en voor zover het geen 100\%-deelneming betreft en in dat geval de integrale methode van consolidatie wordt toegepast. Aldus is de omvang en samenstelling van de consolidatiekring mede bepalend voor de gepresenteerde rentabiliteit, liquiditeit alsmede solvabiliteit.

Door consolidatie worden niet alleen de verhoudingen op de geconsolideerde balans beïnvloed. Het al dan niet meeconsolideren van een deelneming kan ook invloed hebben op het beeld dat de geconsolideerde winst- en verliesrekening en (eventueel) de geconsolideerde staat van herkomst en besteding van middelen tonen.

\section{Regelgeving en praktijk in de Verenigde Staten}

In tegenstelling tot de Nederlandse wetgever en de Raad van de Europese Gemeenschappen is de Financial Accounting Standards Board (FASB) van mening dat 'majority-owned subsidiaries' met afwijkende bedrijfsactiviteiten te allen tijde in de consolidatie dienen te worden opgenomen. Dit kan al worden afgeleid uit de titel van het betreffende Statement (SFAS 94): 'Consolidation of All Majority-owned Subsidiaries' (cursief RGAV). De reden om een uitzondering wegens afwijkende bedrijfsactiviteiten niet op te nemen werd ingegeven door het feit dat in het verleden deze uitzonderingsclausule oneigenlijk werd gebruikt en de vrees dat dit in de toekomst nog verder zou kunnen toenemen. Dit blijkt onder andere uit paragraaf 22: 'This Statement is a major step in resol- ving the growing problem of off-balance-sheet financing. Unconsolidated majority-owned subsidiaries have been a significant aspect of that problem. The growing size and importance of finance and other unconsolidated majorityowned subsidiaries and the resulting amounts of assets, liabilities, revenues, and expenses that have not been reflected in many consolidated financial statements have made the matter important.'

Met het van kracht worden van SFAS 94 is de zogenaamde 'nonhomogeneity exception' zoals geformuleerd in Accounting Research Bulletin No. 51 (ARB 51) komen te vervallen. In paragraaf 3 van ARB 51 wordt onder meer het volgende vermeld: '... For example, separate statements may be required for a subsidiary which is a bank or an insurance company and may be preferable for a finance company where the parent and the other subsidiaries are engaged in manufacturing operations.' (cursief RGAV). Met name het cursief gedrukte gedeelte heeft aanleiding gegeven tot het oneigenlijk gebruik van de uitsluitingsclausule wegens branchevreemde activiteiten.

International Accounting Standard 27 (IAS 27), 'Consolidated Financial Statements and Accounting for Investments in Subsidiaries', sluit nauw aan bij SFAS 94. Het IASC is van mening dat consolidatie-uitsluiting van 'subsidiaries' ${ }^{5}$ met afwijkende bedrijfsactiviteiten geenszins is gerechtvaardigd. Volgens het IASC is het beter deze ondernemingen gewoon mee te consolideren. Wel moet dan additionele informatie worden verstrekt over de diverse bedrijfsonderdelen (paragraaf 12, IAS 27). Vermeldenswaardig in dit kader is dat een verzoek van de Raad voor de Jaarverslaggeving aan het IASC om consolidatie van groepsmaatschappijen met afwijkende bedrijfsactiviteiten te verbieden, indien dat het inzicht in de financiële positie en de behaalde resultaten van het concern in gevaar zou brengen, niet is gehonoreerd. ${ }^{6}$

Uit diverse onderzoeken in de Verenigde Staten is het oneigenlijk gebruik van de 'nonhomogeneity exception' gebleken. Zo werden de jaarrekeningen van 140 ondernemingen met niet meegeconsolideerde financieringsdochters onderzocht 


\section{MAB}

(Heian \& Thies, 1989). Door het niet meeconsolideren van de financieringsdochters bleek dat maar liefst $\$ 230$ miljard vreemd vermogen buiten de geconsolideerde balans werd gehouden. Consolidatie van de financieringsdochters zou leiden tot een stijging van de verhouding vreemd vermogen/totaal vermogen met gemiddeld $12 \%$ (van $58 \%$ naar $65 \%$ ). Deze stijging varieerde voor de diverse bedrijven van $0 \%$ tot $80 \%$. Bovendien werd geconstateerd dat in de periode 1975-1985 een vervijfvoudiging in deze vorm van 'offbalance-sheet'-financiering had plaatsgevonden. Mohr (1988), die behalve de invloed van consolidatie van de financieringsdochters op de gepresenteerde vermogensverhoudingen ook de karakteristieken van de financieringsdochters onderzocht, kwam tot soortgelijke conclusies.

Interessant in dit kader is ook het onderzoek van Livnat \& Sondhi (1986). Zij geven aan dat het niet meeconsolideren van de vooral met vreemd vermogen gefinancierde financieringsdochters niet alleen leidt tot een verbetering van de gepresenteerde financiële ratio's, maar ook dat de variabiliteit van deze ratio's vermindert. Hierdoor wordt de kans kleiner dat afspraken met kredietverschaffers omtrent de financiële ratio's worden geschonden.

\section{Regelgeving in Nederland}

Vóór de aanpassing van de Nederlandse wetgeving aan de Zevende EG-richtlijn was de consolidatieverplichting vastgelegd in het 'oude' artikel 379 lid 6 BW 2. Hierin stond vermeld dat de financiële gegevens omtrent dochtermaatschappijen, al dan niet te zamen met die van de rechtspersoon (de moedermaatschappij) en van andere groepsmaatschappijen, opgenomen dienden te worden in een groepsjaarrekening die volgens de methode van consolidatie was samengesteld, ${ }^{7}$ tenzij het wettelijk vereiste inzicht meer werd gediend door het buiten de consolidatie laten van de desbetreffende rechtspersonen en vennootschappen. Op grond van de laatste zinsnede was het mogelijk maatschappijen niet mee te consolideren, onder andere wegens branchevreemde werkzaamheden. Aldus bevatte de oude wet impliciet een uitzonderingsclausule wegens afwijkende bedrijfsactiviteiten. Door de Raad voor de Jaarverslaggeving werd een dergelijke clausule opgenomen in een ontwerp-Richtlijn (paragraaf 2.03.303).

Bij de verwerking van de Zevende EG-richtlijn in de Nederlandse wetgeving is de consolidatieverplichting geherformuleerd en vastgelegd in artikel 406 BW 2. Lid 1 luidt als volgt: 'De rechtspersoon die ... aan het hoofd staat van zijn groep, neemt in de toelichting van zijn jaarrekening een geconsolideerde jaarrekening op van de eigen financiële gegevens met die van zijn dochtermaatschappijen in de groep en andere groepsmaatschappijen'. Echter wanneer de werkzaamheden van een groepsmaatschappij zodanig afwijken van de andere activiteiten van de groep dat consolidatie strijdig zou zijn met het door de geconsolideerde jaarrekening krachtens artikel 362 lid 1 BW 2 te verschaffen inzicht, dient de desbetreffende groepsmaatschappij niet te worden meegeconsolideerd. De jaarrekening van deze groepsmaatschappij moet dan afzonderlijk in de toelichting worden opgenomen. Deze uitzondering wegens afwijkende bedrijfsactiviteiten is vastgelegd in lid 3 van genoemd artikel. De Zevende EG-richtlijn verplicht de EG-lidstaten onderhavige uitsluitingsclausule in de regelgeving op te nemen (artikel 14 lid 1). ${ }^{8}$

Door de nieuwe wetsbepalingen zijn de mogelijkheden om groepsmaatschappijen met afwijkende bedrijfsactiviteiten buiten de consolidatie te houden ingeperkt. Onder de oude wet diende consolidatie immers 'reeds' achterwege te blijven indien consolidatie niet bijdroeg tot het te verschaffen inzicht, terwijl onder de nieuwe wet 'pas' mag worden afgezien van consolidatie wanneer consolidatie zou leiden tot strijdigheid met dat inzicht.

Overigens zij vermeld dat de nieuwe wettelijke bepalingen inzake de geconsolideerde jaarrekening dienen te worden toegepast op boekjaren die na 31 december 1989 aanvangen. De nieuwe wet mocht echter geheel of ten dele reeds eerder worden toegepast, mits daar in de toelichting melding van werd gemaakt.

Hoewel in de huidige wet expliciet een uitzonderingsclausule wegens afwijkende bedrijfsactiviteiten staat verwoord, geeft de wet niet aan wan- 


\section{MAB}

neer de activiteiten van groepsmaatschappijen dusdanig afwijken van de andere activiteiten van de groep dat het consolideren van bedoelde groepsmaatschappijen zou leiden tot een niet getrouwe weergave van groepsvermogen en -resultaat. Wel heeft de minister van Justitie in zijn Memorie van Antwoord een voorbeeld genoemd, te weten een bank of verzekeringsmaatschappij die groepsmaatschappij is in een groep met andere hoofdwerkzaamheid ${ }^{9}$ (vergelijk het in de vorige paragraaf aangehaalde gedeelte uit ARB $51)$.

Door de Raad voor de Jaarverslaggeving wordt dit in een zogenaamde extra publikatie (het betreft hier geen officiële richtlijn) nader gemotiveerd. De Raad meldt namelijk het volgende: ${ }^{10}$ 'In vele gevallen zullen afwijkende bedrijfsactiviteiten bij consolidatie niet verstorend werken op het beeld dat de geconsolideerde jaarrekening oproept. ${ }^{11}$ Er zijn echter combinaties van activiteiten binnen één concern die moeilijk op dezelfde basis verantwoord kunnen worden. Te denken valt daarbij bijvoorbeeld aan een industriële onderneming met een bank- of verzekeringsbedrijf. In de winst- en verliesrekening zijn begrippen als omzet en bedrijfsresultaat nauwelijks vergelijkbaar en leiden deze voorts tot weinig zeggende ratio's. Met betrekking tot de balans zijn de financieringsverhoudingen voor beide activiteiten veelal sterk uiteenlopend, zodat ook daar consolidatie niet tot een goed inzicht leidt.' Gaarne sluit ik mij bij de mening van de Raad aan. Ik moet daarbij wel aantekenen dat tussen groepsmaatschappijen sterk uiteenlopende financieringsverhoudingen sec geen rol mogen spelen bij de bepaling van de consolidatiekring.

Zowel uit het Memorie van Antwoord als uit de mededeling van de Raad voor de Jaarverslaggeving kan men afleiden dat de uitzonderingsclausule wegens verschil in werkzaamheden zeer restrictief moet worden uitgelegd en zoals uit de vergelijking van de nieuwe met de oude wet blijkt, restrictiever dan in het verleden.

\section{Praktijk in Nederland}

Zoals uit het voorgaande blijkt, hebben de FASB en het IASC de 'nonhomogeneity exception' geschrapt vanwege het oneigenlijk gebruik dat van een dergelijke uitzonderingsclausule zou kunnen worden gemaakt. De Raad van de Europese Gemeenschappen en de Nederlandse wetgever daarentegen zijn daartoe niet overgegaan. Men kan zich nu afvragen in hoeverre in Nederland de uitsluitingsgrond wegens afwijkende bedrijfsactiviteiten oneigenlijk wordt gebruikt. Door het NIvRA (1987) en Van der Tas (1987) is onderzocht in welke mate een beroep werd gedaan op onderhavige uitsluitingsclausule. In deze onderzoeken zijn de jaarrekeningen onderzocht van beursgenoteerde ondernemingen over 1986 respectievelijk 1983/1985. Uit het onderzoek van het NIvRA is gebleken dat slechts twee keer een beroep werd gedaan op de uitzonderingsclausule (onderzoekspopulatie: 120). Van der Tas telde in de jaarrekeningen over 1985 vier gevallen (onderzoekspopulatie: 125). ${ }^{12}$ Hieruit kan men afleiden dat de uitsluitingsclausule wegens branchevreemde activiteiten in Nederland slechts sporadisch wordt gebruikt.

Om na te gaan in hoeverre het gebruik van de uitzonderingsgrond al dan niet gerechtvaardigd is, heb ik de jaarrekeningen over 1988 onderzocht van een honderdtal ondernemingen. ${ }^{13}$

De volgende vijf ondernemingen hebben in de jaarrekening over 1988 één of meer meerderheidsdeelnemingen niet meegeconsolideerd vanwege van de groep afwijkende bedrijfsactiviteiten:

- Vendex International N.V.,

- Naamloze Vennootschap DSM,

- N.V. Koninklijke Nederlandse Vliegtuigenfabriek Fokker,

- DAF N.V. en

- Koninklijke Ahold N.V.

Deze vijf gevallen worden in het navolgende besproken. Het is van belang zich te realiseren dat deze jaarrekeningen onder de oude wettelijke bepalingen inzake de geconsolideerde jaarrekening zijn opgesteld en uitgebracht. Uit geen van de jaarrekeningen kon worden afgeleid dat bij de vaststelling van de consolidatiekring werd uitgegaan van de nieuwe wetsbepalingen. Maar zoals we hiervoor reeds hebben gezien, leidt de nieuwe wettelijke regeling tot een inperking van de moge- 


\section{MAB}

lijkheid om groepsmaatschappijen wegens branchevreemde activiteiten buiten de consolidatie te houden. Met andere woorden, indien onder het oude wettelijke regime ten onrechte een beroep wordt gedaan op de uitzonderingsclausule wegens afwijkende bedrijfsactiviteiten dan geldt dit onder de nieuwe wet a fortiori.

\section{Vendex International N.V. en Naamloze Vennoot-} schap DSM

In de geconsolideerde jaarrekening van Vendex worden in principe alle groepsmaatschappijen meegeconsolideerd. Staal Bankiers N.V., een algemene bank waarin Vendex een $79 \%$-belang heeft, vormt hierop een uitzondering. In het jaarverslag 1988/89 zegt Vendex hierover het volgende: 'De bedrijfsactiviteiten van de meerderheidsdeelneming Staal Bankiers N.V. wijken af van die van het Concern in zijn geheel, waardoor een beter inzicht in vermogen en resultaat wordt bereikt met een afzonderlijke verslaggeving.' De (geconsolideerde) jaarrekening van Staal Bankiers heeft Vendex dan ook separaat opgenomen als bijlage bij de toelichting.

Bij DSM doet zich een vergelijkbare situatie voor. DSM heeft namelijk een 100\%-deelneming in een verzekeringsmaatschappij. 'NV Pensioenverzekeringsmaatschappij DSM wordt niet in de consolidatie betrokken vanwege het branchevreemde karakter van deze vennootschap', aldus DSM in het jaarverslag over 1988. De jaarrekening van de betreffende verzekeringsmaatschappij is echter niet opgenomen in het gepubliceerde DSM-jaarverslag.

De handelwijze van Vendex en DSM om Staal Bankiers respectievelijk Pensioenverzekeringsmaatschappij DSM niet mee te consolideren is onder de oude wet zonder meer verdedigbaar. Door de sterk afwijkende opbouw van de resultaten en de sterk afwijkende aard van de activa en passiva van deze ondernemingen, wordt het door Vendex en DSM door middel van de geconsolideerde jaarrekening te verschaffen inzicht meer gediend met het niet meeconsolideren van Staal Bankiers respectievelijk Pensioenverzekeringsmaatschappij DSM.

Zoals uit het in de vorige paragraaf aangehaalde voorbeeld van de minister van Justitie en de nadere motivering van de Raad voor de Jaarverslaggeving blijkt, is de handelwijze van Vendex en DSM ook onder de nieuwe wet gerechtvaardigd. Hierbij dient wel te worden aangetekend dat binnen de huidige wetgeving in bepaalde gevallen een bank of verzekeringsmaatschappij, onderdeel uitmakend van een industrieel of handelsconcern, toch moet worden meegeconsolideerd. Het meeconsolideren van bijvoorbeeld een kleine bank in een industrieel concern hoeft immers niet strijdig te zijn met het door middel van de geconsolideerde jaarrekening te verschaffen inzicht (in welk geval consolidatie verplicht is, behoudens eventueel verwaarloosbaar belang), terwijl dat inzicht wel meer zou zijn gediend door het buiten de consolidatie houden van deze bank.

\section{N.V. Koninklijke Nederlandse Vliegtuigenfabriek Fokker en DAF N.V.}

Zowel door Fokker als door DAF worden alle meerderheidsdeelnemingen in de consolidatie betrokken, tenzij een beter inzicht wordt verkregen door een afzonderlijke verslaggeving. Dit laatste doet zich volgens Fokker voor bij Aircraft Financing \& Trading B.V., een 100\%-deelneming. Fokker meldt daarover in het jaarverslag 1988 het volgende: 'Gelet op de aard van de onderneming Aircraft Financing \& Trading B.V., te weten financiering en verhuur van vliegtuigen, is de jaarrekening van deze onderneming wel geconsolideerd met die van haar $100 \%$-deelnemingen, doch buiten de consolidatie van de vennootschap gehouden.' De (geconsolideerde) jaarrekening van Aircraft Financing \& Trading is separaat opgenomen.

Ook DAF houdt een soortgelijke deelneming buiten de consolidatie. Het betreft de $100 \%$-deelneming DAF Finance Company N.V. 'De dochtermaatschappij DAF Finance Company N.V. is niet in de geconsolideerde jaarrekening van DAF B.V. ${ }^{14}$ opgenomen vanwege de van de rest van de groep afwijkende aard van de activiteiten', aldus DAF. De (geconsolideerde) balans en resultatenrekening van DAF Finance Company zijn opgenomen in de toelichting.

Het niet meeconsolideren van Aircraft Financing \& Trading en DAF Finance Company door Fokker respectievelijk DAF is onder de oude wettelijke 


\section{MAB}

regeling voor discussie vatbaar. Consolidatie zou naar mijn mening in ieder geval niet strijdig zijn met het wettelijk vereiste inzicht onder de nieuwe wetsbepalingen. Voor beide ondernemingen geldt dat zij ondersteunend zijn voor de verkoop van de Fokker- respectievelijk DAF-produkten. Door middel van afzetfinanciering, waaronder leasing en verhuur, wordt geprobeerd de verkoop te bevorderen. Vanuit die optiek kan men de activiteiten van Aircraft Financing \& Trading en DAF Finance Company tot de normale activiteiten van het Fokker- respectievelijk DAF-concern rekenen.

Consolidatie van Aircraft Financing \& Trading zou bij Fokker slechts een beperkte invloed hebben op de gerapporteerde solvabiliteit; de solvabiliteitsratio ${ }^{15}$ zou dalen van ruim $55 \%$ naar ongeveer $53 \%$. Dit is een gevolg van de relatief beperkte omvang van het bedrijf binnen het Fokker-concern. ${ }^{16}$

Bij DAF daarentegen zou het meeconsolideren van DAF Finance Company tot een substantiële verlaging van de gepresenteerde solvabiliteit leiden; de solvabiliteitsratio zou zakken van ruim $34 \%$ naar circa $23 \%$. Interessant is een vergelijking met de Amerikaanse auto-industrie. Tot het van kracht worden van SFAS 94 was het in de Amerikaanse auto-industrie namelijk gebruikelijk om de financieringsactiviteiten buiten de balans te houden door het niet meeconsolideren van de financieringsdochters. Zo werd door General Motors in het jaarverslag over 1982 een 'debt/ equity'-ratio gerapporteerd van ongeveer 1,3; Ford Motor Co. toonde een verhoudingscijfer van 2,6 . Zouden de financieringsmaatschappijen daarentegen worden meegeconsolideerd, dan zou deze ratio 3,4 respectievelijk 4,9 bedragen; een stijging van $170 \%$ respectievelijk $89 \%$ (Mohr, 1988). Uit de geconsolideerde balans van DAF kan een 'debt/equity'-ratio worden afgeleid van 2,0 . Consolidatie van DAF Finance Company zou evenwel leiden tot een stijging met $70 \%$ tot 3,4 .

\section{Koninklijke Ahold N.V.}

In de groepsjaarrekening van Ahold over 1988 zijn in tegenstelling tot voorgaande jaren de deelnemingen in onroerend goedmaatschappijen niet meer meegeconsolideerd. Daarvoor in de plaats heeft Ahold een zogenaamde samengevoegde balans en resultatenrekening van de onroerend goedmaatschappijen opgenomen. Verder heeft er (en passant) een eenmalige herwaardering plaatsgevonden van het in deze maatschappijen ondergebrachte onroerend goed.

Dit alles naar aanleiding van de verwachting dat Ahold in toenemende mate onroerend goed in eigendom zal krijgen dat niet in gebruik is bij groepsmaatschappijen. 'De daaruit voortvloeiende werkzaamheden verschillen in belangrijke mate van de werkzaamheden die verband houden met onze hoofdactiviteit: de detailhandel in levensmiddelen en andere consumentenprodukten. ... Teneinde een beter inzicht te geven in de omvang en de samenstelling van het vermogen en de behaalde resultaten van de hoofdactiviteit enerzijds en de onroerend goed activiteiten anderzijds worden deze laatste ... niet meer geconsolideerd met de hoofdactiviteit', aldus Ahold in het jaarverslag. Ahold beroept zich aldus op de (verwachte) afwijkende bedrijfsactiviteiten.

Naar mijn mening moeten de activiteiten van de onroerend goedpoot evenwel tot de normale activiteiten van het Ahold-concern worden gerekend. Het betreft hier immers met name winkelpanden die voor het merendeel worden verhuurd aan groepsmaatschappijen. Aldus zijn de activiteiten van de onroerend goedbedrijven (op korte termijn althans) onmisbaar voor het uitvoeren van de hoofdactiviteiten. Bovendien bestaat er beleidsmatig een nauwe verwevenheid tussen de detailhandelspoot en de onroerend goedpoot, bijvoorbeeld met betrekking tot de keuze van de vestigingsplaatsen. ${ }^{17}$

Ook wanneer het in de onroerend goedmaatschappijen ondergebrachte onroerend goed niet (meer) ten dienste zou staan van de andere groepsmaatschappijen, zou mijns inziens (zeker onder de nieuwe wetsbepalingen) tot consolidatie van de onroerend goedbedrijven moeten worden besloten. De diversiteit aan activiteiten binnen de groep zou in dat geval niet van dien aard zijn dat een beroep op de uitzonderingsclausule wegens afwijkende bedrijsactiviteiten. zou zijn gerechtvaardigd (vergelijk de eerste zin van de in de vorige paragraaf aangehaalde passage uit de 


\section{MAB}

mededeling van de Raad voor de Jaarverslaggeving).

Het door middel van een samengevoegde balans en resultatenrekening verschaffen van inzicht in de financiële positie en de resultaten van de onroerend goedsector afzonderlijk gaat ten koste van het inzicht in de financiële positie en de behaalde resultaten van het Ahold-concern als één geheel. Vermeldenswaardig in dit kader is dat in 1982 door Ahold nog het besluit werd genomen alle deelnemingen in onroerend goedmaatschappijen te consolideren juist ter verbetering van genoemd inzicht. De beslissing van Ahold om de onroerend goedbedrijven te deconsolideren is des te opmerkelijker, indien men beziet dat onder de nieuwe wet de uitzonderingsclausule wegens branchevreemde activiteiten restrictiever moet worden toegepast. Bovendien wordt door Ahold notering op een Amerikaanse beurs nagestreefd. ${ }^{18}$ De jaarstukken van Ahold zullen dan in principe aan de Amerikaanse verslaggevingsregels moeten voldoen.

Het verschaffen van inzicht in de financiële positie en de behaalde resultaten van de verschillende activiteiten van het Ahold-concern is geen reden om tot deconsolidatie van de onroerend goedsector over te gaan. Het ware beter geweest om naast de geconsolideerde jaarrekening (inclusief de onroerend goedsector) gediversificeerde informatie te verschaffen over de diverse bedrijfsonderdelen. In het specifieke geval van Ahold kan men evenwel vraagtekens zetten bij het nut van het separaat tonen van de resultaten van de onroerend goedsector; deze worden immers sterk beïnvloed door de prijsstelling van 'intercompany'-transacties en zijn daardoor min of meer kunstmatig van aard. Overigens moet worden opgemerkt dat de mate waarin en de wijze waarop zowel geaggregeerde als gesegmenteerde informatie wordt verstrekt, in principe los dient te staan van de wijze waarop een onderneming is opgebouwd; het maakt daarbij niet uit of de diverse activiteiten zijn ondergebracht in afzonderlijke juridische eenheden of dat alle activiteiten zijn ondergebracht in één juridische eenheid (met diverse afdelingen).

Het niet meeconsolideren door Ahold van de vooral met vreemd vermogen gefinancierde onroerend goedsector, gecombineerd met de herwaardering van het onroerend goed, had onder andere tot gevolg dat de getoonde solvabiliteitsratio in 1988 niet daalde van $32 \%$ naar $24 \%$, maar van $32 \%$ naar $28 \%$. De daling van de sedert 1982 vrij stabiele solvabiliteitsratio (ongeveer $32 \%$ ) werd aldus met ongeveer de helft teruggebracht. De verslechtering van de feitelijke vermogenspositie was met name een gevolg van het hoge investeringsniveau ( ruim $f 1$ miljard) in 1988. Zo werd in de Verenigde Staten de FNSsupermarktketen overgenomen.

\section{Evaluatie}

In de door mij onderzochte jaarverslagen over 1988 werd vijf maal een beroep op de uitsluitingsclausule wegens afwijkende bedrijfsactiviteiten geconstateerd. Naar mijn mening was deze gedragslijn onder de oude wetsbepalingen in drie gevallen op zijn minst voor discussie vatbaar, terwijl onder de huidige wettelijke regeling van een beroep op de uitzonderingsclausule zou moeten worden afgezien.

Van toestanden zoals die zich in de Verenigde Staten voordeden, is in Nederland geen sprake. Toch dient te worden voorkomen dat de wijze waarop Ahold, DAF en Fokker de uitzonderingsclausule interpreteren een precedent schept voor andere bedrijven, zeker nu de uitsluitingsclausule in de nieuwe wet restrictiever is geformuleerd.

Het eventueel laten vervallen van de uitzonderingsclausule a la IAS 27 of SFAS 94 is naar mijn mening niet wenselijk. Nog afgezien van de vraag of dat binnen het kader van de Zevende EG-richtlijn wel mogelijk is.

In Nederland geeft Marseille (1989, pagina 74) aan wel voor een dergelijke regeling te voelen indien de regelgeving met betrekking tot de door ondernemingen te verstrekken gesegmenteerde informatie wordt uitgebreid. Naar mijn mening is deze oplossing niet bevredigend. Ik ben het eens met Timmers (1989, pagina 19) als hij zegt: 'Segmentatie kan niet als een echte oplossing beschouwd worden omdat het "kwaad" dan al geschied is, immers in de primaire balans en winst- en verliesrekening zijn de per definitie niet bij elkaar op te tellen activiteiten al bij elkaar 


\section{MAB}

opgeteld. Dit moet dan gerepareerd worden door middel van de toelichting.' Het ene gat (potentieel misbruik) wordt als het ware gestopt met het andere (in bepaalde gevallen geen adequaat inzicht in de financiële positie en de behaalde resultaten van het concern als economische eenheid).

Naar mijn mening kan de uitsluitingsclausule zoals die in de huidige wet staat geformuleerd wel verder worden aangescherpt. Bijvoorbeeld door in de Richtlijnen voor de jaarverslaggeving expliciet aan te geven in welke situaties sprake is van afwijkende bedrijfsactiviteiten die het niet meeconsolideren van een groepsmaatschappij rechtvaardigen. Hetgeen de Raad voor de Jaarverslaggeving over dit onderwerp heeft gemeld in de hiervoor genoemde extra publikatie kan daartoe als aanzet dienen. Door een nadere concretisering in de Richtlijnen van artikel 406 lid 3 BW 2 kan de 'manoeuvreerruimte', voor zowel de opstellers als de controleurs van jaarrekeningen, worden beperkt zonder dat dit ten koste gaat van het inzicht dat een geconsolideerde jaarrekening dient te verschaffen.

\section{Bijlage: Lijst van ondernemingen betrokken bij het onderzoek}

Aalberts Industries N.V., Venlo

ACF Holding N.V., Maarssen

Koninklijke Ahold N.V., Zaandam

Ahrend Groep N.V., Amsterdam

Akzo N.V., Arnhem

Atag Holding N.V., Ulft

BAM Holding N.V., Bunnik

Batenburg Beheer N.V., Rotterdam

Beers N.V., Den Haag

N.V. Koninklijke Nederlandsche Machinefabriek v/h

E. H. Begemann, Helmond

Maatschappij van Berkel's Patent N.V., Rijswijk

Blydenstein-Willink N.V., Enschede

De Boer Winkelbedrijven N.V., Beilen

N.V. Koninklijke Distilleerderijen Erven Lucas Bols,

Nieuw-Vennep

Koninklijke Borsumij Wehry N.V., Den Haag

Koninklijke Boskalis Westminster N.V., Papendrecht

Bührmann-Tetterode N.V., Amsterdam

Center Parcs N.V., Rotterdam

N.V. Centrale Suiker Maatschappij, Diemen ${ }^{a}$

Cindu-Key \& Kramer N.V., Uithoorn

DAF N.V., Eindhoven
Tapijtfabriek H. Desseaux N.V., Oss ${ }^{b}$

Naamloze Vennootschap DSM, Heerlen

Elsevier N.V., Amsterdam

Eriks Holding N.V., Alkmaar

Flexovit International N.V., Eibergen

N.V. Koninklijke Nederlandse Vliegtuigenfabriek

Fokker, Amsterdam

Frans Maas Beheer N.V., Venlo

Furness N.V., Rotterdam

Gamma Holding N.V., Helmond

Getronics N.V., Amsterdam

Van der Giessen-de Noord N.V., Krimpen aan den IJssel

Koninklijke Gist-brocades N.V., Delft

Goudsmit N.V., De Bilt

Grasso's Koninklijke Machinefabrieken N.V.,

Den Bosch

Grolsche Bierbrouwerij N.V., Enschede

N.V. GTI Holding, Nieuwegein

Hagemeyer N.V., Naarden

HCS Technology N.V., Apeldoorn

Heineken N.V., Amsterdam

N.V.W. A. Hoek's Machine- en Zuurstoffabriek, Schiedam Holland Sea Search Holding N.V., Den Haag

Hollandia Kloos Holding N.V., Krimpen aan den IJssel

Koninklijke Nederiandsche Hoogovens en Staalfabrieken

N.V., IJmuiden

Hunter Douglas N.V., Rotterdam

Ingenieurs Bureau Bouwnijverheid-Kondor Groep N.V., Leiden

IHC Caland N.V., Schiedam

N.V. Industrieele Maatschappij, Den Haag

Internatio-Müller N.V., Rotterdam

N.V. Koninklijke Bijenkorf Beheer KBB, Amsterdam ${ }^{\text {b }}$

Koninklijke Luchtvaart Maatschappij N.V., Amstelveen ${ }^{b}$

Koninklijke Nederlandse Papierfabrieken N.V., Naarden

N.V. Koninklijke Nederlandsche Petroleum Maatschappij,

Den Haag

Koninklijke Nederlandsche Springstoffenfabrieken N.V.,

Bussum

Grand Hotel Krasnapolsky N.V., Amsterdam

Koninklijke Landré \& Glinderman N.V., Diemen

Macintosh N.V., Stein

N.V. Medicopharma, Zaandam

Nagron Nationaal Grondbezit N.V., Den Haag

NBM-Amstelland N.V., Den Haag

N.V. Nederlandsche Apparatenfabriek Nedap, Groenlo

Koninklijke Nedlloyd Groep N.V., Rotterdam

NKF Holding N.V., Delft

Norit N.V., Amersfoort

N.V. Verenigde Bedrijven Nutricia, Zoetermeer

Koninklijke Nijverdal-Ten Cate N.V., Almelo

Océ-van der Grinten N.V., Venloa

Van Ommeren Ceteco N.V., Rotterdam

Oldelft Groep N.V., Delft

OTRA N.V., Amstelveen

Pakhoed Holding N.V., Rotterdam

Palthe N.V., Almelo 
N.V. Philips' Gloeilampenfabrieken, Eindhoven

Polynorm N.V., Bunschoten

Reesink N.V., Zutphen

Riva N.V., Hoofddorp

N.V. Rubber Cultuur Maatschappij 'Amsterdam',

Amsterdam

Samas-Groep N.V., Utrecht ${ }^{\mathrm{b}}$

Schuitema N.V., Amersfoort

Smit Internationale N.V., Rotterdam

N.V. Koninklijke Sphinx, Maastricht ${ }^{\mathrm{b}}$

Verenigde machinefabrieken Stork N.V., Naarden

N.V. Holdingmaatschappij De Telegraaf, Amsterdam

Textielgroep Twenthe N.V., Almelo

Tulip Computers N.V., Den Bosch

N.V. Twentsche Kabel Holding, Haaksbergen

Ubbink N.V., Doesburg

Unigro N.V., Houten ${ }^{\mathrm{b}}$

Unilever N.V., Rotterdam

Union N.V., Nieuwleusen

Vendex International N.V., Amsterdam ${ }^{\mathrm{b}}$

N.V. Verto, Rotterdam

N.V. Verenigd Bezit VNU, Haarlem

Koninklijke Volker Stevin N.V., Rotterdam

Volmac Software Groep N.V., Utrecht

Vredestein N.V., Velp

VRG-Groep N.V., Diemen

Wegener Tijl N.V., Apeldoorn

Koninklijke Wessanen N.V., Amstelveen

Wolters Kluwer N.V., Amsterdam

a Het betreft hier een onderneming met een gebroken boekjaar; onderzocht is de jaarrekening over 1987/88.

b Het betreft hier een onderneming met een gebroken boekjaar; onderzocht is de jaarrekening over 1988/89.

\section{Literatuur}

Beckman H. (red.), Consolidatiewet en jaarrekening, NIvRAgeschrift 51, Kluwer, Deventer, 1989.

Beckman H. \& Van Hoepen M. A., Deelnemingen en groepsjaarrekening, Euroforum, Eindhoven, 1984.

Beckman H. \& Volgenant jr. O. M. (red.), Documentatie rond de jaarrekening, Kluwer, Deventer, bijgewerkt tot en met mei 1989.

Enquêtecommissie OGEM (Van der Hoeven J., Van Putten A. \& Slagter W. J.), Verslag van het onderzoek aan de Ondernemingskamer, 31 december 1986.

Financial Accounting Standards Board, Statement of Financial Accounting Standards No. 94: Consolidation of All Majorityowned Subsidiaries, Stamford, Connecticut, 1987.

Heian J. B. \& Thies J. B., Consolidation of Finance Subsidiaries: $\$ 230$ Billion in Off-Balance-Sheet Financing Comes Home to Roost, Accounting Horizons, maart 1989.

Livnat J. \& Sondhi A. C., Finance Subsidiaries: Their Formation and Consolidation, Journal of Business Finance \& Accounting, lente 1986.
Marseille $\mathrm{H}$., Consolidatie en groepsregelingen, in: Beckman $\mathrm{H}$. (red.), Ontwikkelingen in de financiële verslaggeving: grondslagen en praktijk, Kluwer, Deventer, 1989.

Mohr R. M., Unconsolidated Finance Subsidiaries: Characteristics and Debt/Equity Effects, Accounting Horizons, maart 1988.

Nederlands Instituut van Registeraccountants, Onderzoek Jaarverslaggeving 1984, NlvRA-geschrift 39, Kluwer, Deventer, 1985.

Nederlands Instituut van Registeraccountants, Onderzoek Jaarverslaggeving 1986, NIvRA-geschrift 42, Kluwer, Deventer, 1987.

Raad voor de Jaarverslaggeving, Richtlijnen voor de jaarverslaggeving, Kluwer, Deventer, bijgewerkt tot en met augustus 1989.

Van der Tas L. G., Groepsverslaggeving, in: Dijksma J. (red.), Jaar in - jaar uit 2, Wolters-Noordhoff, Groningen, 1987.

Timmers M. P., Nieuwe wettelijke bepalingen voor de geconsolideerde jaarrekening, Maandblad voor Accountancy en Bedrijfseconomie, januari/februari 1989.

\section{Noten}

1 De MAB-redactie dank ik voor het waardevolle commentaar op de concept-versie van dit artikel.

2 In dit blad is eerder over deze materie geschreven, bijvoorbeeld door Timmers (1989).

3 Deze uitzondering heeft een verplichtend karakter. Andere (facultatieve) uitzonderingen zijn:

- groepsmaatschappijen waarvan het gezamenlijk belang van te verwaarlozen betekenis is;

- groepsmaatschappijen waarvan de benodigde gegevens slechts tegen onevenredige kosten of met grote vertraging te verkrijgen of te ramen zijn;

- groepsmaatschappijen waarin het belang slechts gehouden wordt ter vervreemding;

- groepen die de omvang van kleine onderneming niet overschrijden.

4 In Nederland dienen alle deelnemingen waarin men invloed van betekenis uitoefent op het zakelijke en financiële beleid in principe te worden gewaardeerd tegen de nettovermogenswaarde (zie artikel $389 \mathrm{BW}$ 2).

5 Door het IASC wordt het begrip 'subsidiary' als volgt gedefinieerd: 'A subsidiary is an enterprise that is controlled by another enterprise (known as the parent).' Zie paragraaf 3, IAS 22.

6 Brief van de Raad voor de Jaarverslaggeving aan het IASC d.d. 24 februari 1988.

7 Uit deze formulering kon worden afgeleid dat in principe dochtermaatschappijen steeds moesten worden meegeconsolideerd, dan wel dat slechts groepsmaatschappijen mochten worden meegeconsolideerd.

Op de vraag ten aanzien van welke maatschappijen een consolidatieplicht dan wel een consolidatiebevoegdheid gold, wordt niet nader ingegaan. Verwezen zij onder meer naar Beckman (1989, hoofdstuk I) en Beckman \& Van Hoepen (1984, paragraaf 9.2). Ook zal niet worden ingegaan op de verschillen in 
definiëring van de begrippen dochtermaatschappij en groepsmaatschappij onder de oude en nieuwe wet. Zie hiervoor onder meer Timmers (1989).

8 Lid 2 van dit artikel luidt als volgt: 'Lid 1 is niet reeds van toepassing wanneer de in de consolidatie op te nemen ondernemingen deels industriële, deels commerciële en deels dienstverlenende ondernemingen zijn, of wanneer deze ondernemingen industriële of commerciële werkzaamheden uitoefenen die betrekking hebben op uiteenlopende produkten dan wel uiteenlopende diensten verrichten.'

Hieruit kan worden afgeleid dat zogenaamde 'gemengde groepen', dat wil zeggen groepen met diverse activiteiten, geen beroep op de uitzonderingsclausule kunnen doen.

9 Memorie van Antwoord d.d. 27 oktober 1987; Tweede Kamer, vergaderjaar 1987-1988, 19813, nr. 5.

10 Raad voor de Jaarverslaggeving. Extra publikatie inzake Bijzondere bepalingen voor de geconsolideerde jaarrekening en Enige vereenvoudigingen en verduidelijkingen in het jaarrekeningenrecht, augustus 1989, pagina 10.

11 Vergelijk artikel 14 lid 2 van de Zevende EG-richtlijn (zie noot 8).

12 Het zij vermeld dat de resultaten van beide onderzoeken niet geheel met elkaar overeenstemmen. Zowel het NIvRA als Van der Tas hebben de jaarrekeningen over 1984 onderzocht. Het NlvRA echter telde slechts twee gevallen, terwijl Van der Tas vijf gevallen telde waarin een beroep werd gedaan op de uitsluitingsclausule wegens afwijkende bedrijfsactiviteiten. Bij Van der Tas betrof het de volgende ondernemingen: Boskalis, Fokker, Heineken, Hoogovens en Internatio Muller. De afwijking tussen de resultaten van de beide onderzoeken werd onder meer veroorzaakt door verschillen in de onderzoekspopulatie. Zo maakte de jaarrekening van Boskalis geen deel uit van het NIVRA-onderzoek. Verder kunnen ook interpretatieverschillen een rol hebben gespeeld; door Van der Tas werd Heineken genoemd, dat in het jaarrapport over 1984 het gebruik van de uitzonderingsclausule wel vermeldde, terwijl die in dat jaar niet van toepassing was.

13 Het betreft hier uitsluitend niet-financiële instellingen. Met uitzondering van Unigro en Vendex International waren de aandelen van deze ondernemingen op 31 december 1989 ter beurze van Amsterdam genoteerd.

14 De naam van deze vennootschap is in 1989 gewijzigd in DAF N.V.; sedert juni 1989 zijn de DAF-aandelen beursgenoteerd. 15 De solvabiliteitsratio wordt in deze paragraaf gedefinieerd als het garantievermogen gedeeld door het totaal vermogen. Het garantievermogen omvat het eigen vermogen en voor zover van toepassing, het belang derden, de egalisatierekening investeringspremies en de achtergestelde leningen.

16 Voor de goede orde zij vermeld dat onlangs de helft van de aandelen Aircraft Financing \& Trading zijn verkocht aan RollsRoyce \& Partners Finance (zie onder meer NRC/Handelsblad d.d. 3 februari 1990 en 10 mei 1990). Op grond daarvan zou Aircraft Financing \& Trading voortaan niet meer behoeven te worden meegeconsolideerd. Een en ander doet evenwel geen afbreuk aan de onderhavige problematiek, namelijk de wijze waarop de uitsluitingsclausule wegens afwijkende bedrijfsactiviteiten zou moeten worden geïnterpreteerd.
17 Interessant in dit kader is de kritiek van de enquêtecommissie OGEM omtrent het niet meeconsolideren van de meerderheidsdeelnemingen in onroerend goed maatschappijen door OGEM Holding N.V. De commissie, die in opdacht van de Ondernemingskamer het beleid en de gang van zaken bij OGEM in de periode 1970-1983 onderzocht, vond het bedenkelijk dat de balansverhoudingen bewust gunstiger werden voorgesteld, onder andere door het (tot 1980) buiten de balans houden van het zogenaamde bedrijfsgebonden onroerend goed. Ter verbetering van de kwaliteit van de jaarrekening werd door OGEM besloten om met ingang van 1980 de onroerend goed maatschappijen mee te consolideren (zie het versiag van de enquêtecommissie, pagina 105). In het OGEM-jaarverslag over 1980 wordt hierover het volgende gemeld: '... Tot deze wijziging van de consolidatiegrondslagen is besloten naar aanleiding van de bij de Tweede Kamer der Staten-Generaal ingediende Aanpassingswetgeving inzake het vennootschapsrecht (aanpassing van de wetgeving aan de Vierde EG-richtlijn, RGAV). In deze Aanpassingswetgeving wordt een duidelijke voorkeur uitgesproken voor consolidatie in de jaarrekening van de moedermaatschappij van deelnemingen zoals deze onroerend goed maatschappijen.'

18 Zie onder meer NRC/Handelsblad d.d. 12 oktober 1989. 